ФЕДЕРАЛЬНЫЙ НАУЧНО-ИССЛЕДОВАТЕЛЬСКИЙ СОЦИОЛОГИЧЕСКИЙ ЦЕНТР РОССИЙСКОЙ АКАДЕМИИ НАУК ИНСТИТУТ СОЦИАЛЬНО-ПОЛИТИЧЕСКИХ ИССЛЕДОВАНИЙ

\title{
ЦИФРОВИЗАЦИЯ: ЗАВТРА НАЧАЛОСЬ ВЧЕРА
}

Москва

Издательство «Проспект»

2020 
УДК 32.019 .52

ББК 60.561 .3

Ц75

Утверждено к публикации Учёным советом Института социально-политических исследований Федерального научно-исследовательского социологического центра РАН

Рецензенты:

д-р полит. наук, проф. Л. Е. Ильичева

д-р филос. наук, проф. И. В. Орлова

Авторский коллектив:

М. И. Бесхмельницин, С. В. Рогачев, А. Д. Заточная, А. В. Иванов, Н. П. Кононкова, Н. В. Мерзликин, Н. П. Сащенко, Е. П. Сигарева

Цифровизация: завтра началось вчера / М. И. Бесхмельницин, Ц75 С. В. Рогачев [и др.]; ФНИСЦ РАН. - М.: Изд-во «Проспект», 2020. $-32 \mathrm{c}$.

DOI 10.38085/978-5-985974-41-6-2020-1-32

ISBN 978-5-98597-441-6

Брошюра посвящена актуальным вопросам изучения процесса вхождения России в новую цифровую реальность. В ходе экспертного опроса, проведенного среди государственных и муниципальных служащих и представителей научного сообщества определены и проанализированы наиболее важные сферы социально-политической жизни, глубина и характер влияния на них широкого применения цифровых технологий.

Издание рассчитано на специалистов государственного и муниципального управления, госслужащих и представителей научного сообщества: политологов, социологов, демографов, психологов, экономистов и др., а также аспирантов и студентов, всех интересующихся вопросами социального прогнозирования и политической рискологии.

УДК 32.019 .52

ББК 60.561 .3

ISBN 978-5-98597-441-6

(C) Авторы, текст, 2020

(C) ФНИСЦ РАН, 2020 


\section{Оглавление}

Введение ..........................

1. Актуальность исследования. . . . . . . . . . . . . . . .6 6

2. Идеологическое обеспечение цифрового проекта. . . . . . . . . . .8

3. Возможности цифровой экономики в экспертных оценках . . . . . . 9

4. Социальная среда процесса цифровизации . . . . . . . . . . . 11

5. Факторы, отрицательно влияющие на процесс формирования цифровой среды. . . . . . . . . . . . . . . 13

6. Социально-политические риски цифровой экономики в экспертных оценках . . . . . . . . . . . . . . 15

7. Демографическая динамика в России: риски для национального проекта «Цифровая экономика» . . . . . 18

8. Особенности формирования новой цифровой элиты в России . . . 20

9. Роль государства в цифровой трансформации

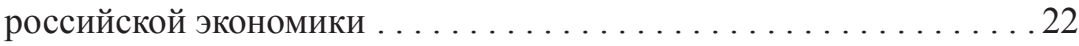

10. Основные выводы по I этапу экспертного мониторинга. . . . . . . 24

11. Предложения . . . . . . . . . . . . . . . . . . . . . . . 26

Заключение . . . . . . . . . . . . . . . . . . . . . . . . 28

Список литературы . . . . . . . . . . . . . . . . . . 30

Сведения об авторах .......................... 31 


\section{ВВЕДЕНИЕ}

Научная проблема, на решение которой направлен исследовательский проект, состоит в разработке концептуально-методологического компонента процесса упреждения, нейтрализации и исследования рисков и вызовов национальной безопасности, устойчивости российской государственности в условиях глобальных изменений в мире, решения Россией стратегических задач по формированию нового технологического уклада, цифровизации.

Экспертные оценки свидетельствуют, что кризис мировой экономики, пандемия коронавируса - лишь внешнее проявление глубокого и всеобъемлющего изменения в мире. Цивилизация входит в новую стадию своего развития. Начался глобальный переход к качественно новому состоянию, к принципиально новой организации человеческого сообщества. Мир входит в состояние геополитической неопределенности, непредсказуемости и смуты. Кризис, который проявился в связи с пандемией коронавируса, стал таким глобальным и всеобъемлющим, что возврат к ситуации, которая существовала накануне, уже невозможна. Подошло время фундаментальных перемен, переход к принципиально новой организации человеческого общества.

Наступает и новый этап в жизни России, этап формирования нового технологического уклада, в основе которого цифровизация, нацеленная на прорыв в технологическом развитии страны, на создание высокотехнологического сектора экономики. Период геополитической неопределенности, нарастания глобальных финансовых потрясений, необходимость преодоления последствий пандемии коронавируса ставит под угрозу сроки выполнения комплекса национальных программ, реализуемых в соответствии с президентским Указом «О националь- 
ных целях и стратегических задачах развития Российской Федерации на период до 2024 года».

Все это обуславливает необходимость комплексной оценки и исследования вызовов и угроз национальной безопасности, формирующихся как извне, так и внутри российского общества.

В брошюре нашли отражение основные результаты и аналитические выводы по проведенным исследованиям. Однако события планетарного масштаба 2020 г., связанные с возникновением и стремительным распространением пандемии инфекционного заболевания COVID-19, уже на первых этапах развития этого процесса показали, что цифровизация общественной жизни и экономики государств может оказать значительно более существенное влияние на процесс формирования нового мира. Это делает данный проект не только актуальным, но и требует ускорения его реализации, так как риски социально-политического и социально-экономического характера в условиях нового технологического уклада могут сочетаться с угрозами, появление которых ранее нельзя было даже спрогнозировать. 


\section{1. АКТУАЛЬНОСТЬ ИССЛЕДОВАНИЯ}

Российская Федерация, как и многие страны мира, постепенно входит в новый цивилизационный уклад, в цифровую реальность. Цифровая доминанта становится важнейшим фактором общественного развития, который приобретает фундаментальное значение для национальной безопасности страны. Новый глобальный вызов - коронавирусная инфекция (COVID-19) - сегодня подтверждает неготовность человеческой цивилизации прогнозировать и противостоять угрозам планетарного масштаба, в сжатые сроки консолидировать ресурсы и вырабатывать единую стратегию действий по нейтрализации цивилизационных рисков. Цифровизация всех сфер жизни общества сегодня предоставляет при помощи информационно-коммуникационных технологий уникальную возможность объединения интеллектуального потенциала, научных разработок, результатов исследований научных школ и направлений, ведущихся в различных странах.

Пандемия планетарного масштаба диктует жизненно важную необходимость стремительно внедрить и опробовать цифровые технологии в разных сферах народного хозяйства. Из-за опасений утраты значительного числа жизней срочно были переведены на удаленную работу многие отрасли экономики. Цифровые технологии тотально распространились на образовательную сферу и стали применяться в повседневной жизни. Экстремальное кризисное цифровое управление в условиях пандемии, в свою очередь, выявило значительные проблемы самого технологического новшества, которые, возможно, в более благоприятных условиях не были бы столь критичны. Однако именно сложившаяся современная ситуация позволит оценить зна- 
чимость результатов нашего проекта, которые были получены еще до планетарного кризиса.

Результаты наших исследований показали, что сформировался и все более укрепляется специфический социально-политический фон, включающий различные (разнопорядковые) политические и социальные риски, активно влияющие на ход и результативность процессов цифровизации. Многие из них носят системный характер. Эти риски часто не отслеживаются и не осмысливаются. Они пока не стали предметом серьезного научного исследования и обсуждения на конференциях и симпозиумах по процессам цифровизации.

В ходе I этапа мониторинга был осуществлен опрос 139 экспертов, представляющих 8 ключевых регионов РФ: Москва, Московская обл., Санкт-Петербург, Курск, Белгород, Екатеринбург, Омск, Комсомольскна-Амуре.

Многоступенчатая процедура отбора экспертов предусматривала учет четырех основных критериев, соответствие которым позволяло включить намеченного кандидата в число экспертов:

1 - область профессиональной деятельности эксперта;

2 - уровень квалификации эксперта;

3 - стаж работы эксперта на занимаемой должности;

4 - независимость и беспристрастность эксперта.

Исследование имело своей главной целью получение экспертной информации от действующих управленцев о реальной практике реализации программы цифровизации на местах, с одной стороны, и оценки хода этого процесса с точки зрения научной методологии его реализации в России учеными - представителями крупнейших научных центров страны, с другой.

В докладе также представлен сравнительный анализ экспертных мнений представителей ученого сообщества, полученных в ходе проведения экспертных опросов, круглых столов и научных дискуссий по данной проблематике в течение 2018-2019 гг. 


\section{2. ИДЕОЛОГИЧЕСКОЕ ОБЕСПЕЧЕНИЕ ЦИФРОВОГО ПРОЕКТА}

Экспертное сообщество консолидировано высказывает мнение, что цифровые технологии оказались вне основных трендов восприятия общественно-политической ситуации. Значительно осложняет успешное осуществление стратегии «Цифрового прорыва» отсутствие широкой информационной поддержки средств массовой информации и, прежде всего, центральных каналов телевидения.

Сегодня все более актуальным становится теоретическое осмысление основных направлений формирующейся российской реальности под влиянием развивающихся цифровых технологий и возникающих при этом социально-политических рисков. Сложилась ситуация, когда общество делает ставку в своем развитии на цифровой прорыв, не имея его корректного теоретического обоснования. Чрезвычайно важным становится вопрос восприятия населением целостной идеологии цифровизации, направленной на решение важнейших проблем социального государства. 


\section{3. ВОЗМОЖНОСТИ ЦИФРОВОЙ ЭКОНОМИКИ В ЭКСПЕРТНЫХ ОЦЕНКАХ}

Результаты опроса показывают довольно высокий уровень позитивных оценок экспертами возможностей цифровизации (см. табл. 1).

Таблица 1

Согласны ли Вы с тем, что цифровая экономика открывает новые возможности для развития страны и в какой мере?

( $\mathrm{N}=127, \%$ от числа опрошенных экспертов)

\begin{tabular}{|c|l|c|c|c|}
\hline Ранг & \multicolumn{1}{|c|}{$\begin{array}{c}\text { Возможности цифровой } \\
\text { экономики }\end{array}$} & $\begin{array}{c}\text { В невысокой } \\
\text { мере }\end{array}$ & $\begin{array}{c}\text { В средней } \\
\text { мере }\end{array}$ & $\begin{array}{c}\text { В высокой } \\
\text { мере }\end{array}$ \\
\hline 1 & $\begin{array}{l}\text { Новые возможности для } \\
\text { появления прорывных } \\
\text { технологий, инновационного } \\
\text { развития производственной } \\
\text { сферы }\end{array}$ & 4,7 & 16,5 & 78,8 \\
\hline 2 & $\begin{array}{l}\text { Новые возможности в сфере } \\
\text { образования }\end{array}$ & 6,7 & 20,0 & 73,3 \\
\hline 3 & $\begin{array}{l}\text { Рост производительности труда, } \\
\text { автоматизация, роботизация } \\
\text { произвоства }\end{array}$ & 9,5 & 18,3 & 72,2 \\
\hline 4 & $\begin{array}{l}\text { Новые возможности в системе } \\
\text { государственного управления, } \\
\text { повышение его эффекивности } \\
\text { и социальной направленности }\end{array}$ & 9,5 & 20,6 & 69,9 \\
\hline 5 & $\begin{array}{l}\text { Выведение медицины } \\
\text { на качественно новый } \\
\text { технологический уровень } \\
\text { развития }\end{array}$ & 14,3 & 19,8 & 65,9 \\
\hline 6 & $\begin{array}{l}\text { Новые возможности для } \\
\text { общения людей, создания } \\
\text { комфортной среды проживания }\end{array}$ & 13,6 & 26,0 & 60,4 \\
\hline
\end{tabular}


Окончание табл. 1

\begin{tabular}{|c|l|c|c|c|}
\hline Ранг & \multicolumn{1}{|c|}{$\begin{array}{c}\text { Возможности цифровой } \\
\text { экономики }\end{array}$} & $\begin{array}{c}\text { В невысокой } \\
\text { мере }\end{array}$ & $\begin{array}{c}\text { В средней } \\
\text { мере }\end{array}$ & $\begin{array}{c}\text { В высокой } \\
\text { мере }\end{array}$ \\
\hline 7 & $\begin{array}{l}\text { Новые возможности для } \\
\text { реализации стратегического } \\
\text { прорыва в число лидеров } \\
\text { мирового развития }\end{array}$ & 15,3 & 25,8 & 58,9 \\
\hline 8 & $\begin{array}{l}\text { Новые возможности } \\
\text { в пропаганде национальных } \\
\text { ценностей и разьяснении } \\
\text { российской политики на } \\
\text { международной арене }\end{array}$ & 28,8 & 32,0 & 39,2 \\
\hline 9 & $\begin{array}{l}\text { Новые возможности для } \\
\text { укрепления морально- } \\
\text { политичского единства } \\
\text { российского общества и его } \\
\text { консолидации }\end{array}$ & 45,2 & 32,5 & 22,3 \\
\hline 10 & $\begin{array}{l}\text { Новые возможности для } \\
\text { гуманизации общественных } \\
\text { отношений, укрепления } \\
\text { нравственных основ жизни }\end{array}$ & 47,6 & 26,2 & 26,2 \\
\hline
\end{tabular}

По мнению экспертов, существует устойчивая связь высоких возможностей цифровой экономики, прежде всего, со сферой производства, а также с образованием и медициной. Реализация этих возможностей и предопределяет потенциал выхода России в число лидеров мирового развития, оцененный экспертами достаточно высоко $(58,4 \%)$.

Обращают на себя внимание довольно низкие оценки экспертами возможностей цифровой экономики в решении проблем, затрагивающих социально-политическую сферу. Невысоко оценены возможности цифровой экономики в гуманизации общественных отношений, укреплении нравственных основ жизни. На низком уровне в оценках экспертов находятся возможности цифровизации в решении проблем консолидации общества. 


\section{4. СОЦИАЛЬНАЯ СРЕДА ПРОЦЕССА ЦИФРОВИЗАЦИИ}

В процессе реализации национального проекта цифрового развития значительную роль играет уровень его поддержки в социуме. Показательна иерархия экспертных оценок социальной среды, выстроенная по параметру «в высокой мере» (см. табл. 2).

В какой мере, на Ваш взгляд, поддерживается необходимость ускоренного вхождения России в русло технологической революции?

$(\mathrm{N}=127, \%$ от числа опрошенных экспертов, ранжированы по параметру «в высокой мере»)

\begin{tabular}{|c|l|c|c|c|}
\hline Ранг & \multicolumn{1}{|c|}{$\begin{array}{c}\text { Субъекты социальной } \\
\text { структуры }\end{array}$} & $\begin{array}{c}\text { В невысокой } \\
\text { мере }\end{array}$ & $\begin{array}{c}\text { В средней } \\
\text { мере }\end{array}$ & $\begin{array}{c}\text { В высокой } \\
\text { мере }\end{array}$ \\
\hline 1 & $\begin{array}{l}\text { Научная среда, сфера } \\
\text { образования }\end{array}$ & 5,7 & 30,3 & 64,0 \\
\hline 2 & Корпоративный бизнес & 11,4 & 29,3 & 59,3 \\
\hline 3 & $\begin{array}{l}\text { Властные структуры } \\
\text { федерального уровня }\end{array}$ & 10,0 & 31,7 & 58,3 \\
\hline 4 & $\begin{array}{l}\text { Государственный сектор } \\
\text { экономики }\end{array}$ & 13,4 & 37,0 & 49,6 \\
\hline 5 & $\begin{array}{l}\text { Международные партнеры } \\
\text { России }\end{array}$ & 29,2 & 21,7 & 49,1 \\
\hline 6 & $\begin{array}{l}\text { Властные структуры } \\
\text { регионального уровня }\end{array}$ & 24,6 & 35,2 & 40,2 \\
\hline 7 & Граждане России & 35,0 & 33,3 & 31,7 \\
\hline 8 & $\begin{array}{l}\text { Политические партии } \\
\text { и движения }\end{array}$ & 35,5 & 33,9 & 30,6 \\
\hline 9 & Средний и малый бизнес & 34,7 & 36,4 & 28,9 \\
\hline
\end{tabular}


Первые места в иерархии оценок принадлежат науке, сфере образования, крупному частному бизнесу и федеральным структурам власти. За ними следует государственный сектор экономики. В высокой степени консолидированные оценки получены от экспертов представителей властных структур регионального и муниципального уровней.

Данные исследования свидетельствуют, что в массовом сознании граждан России еще не наступил качественный перелом в отношении к процессу цифровизации и тем возможностям, которые она предоставляет обществу. Аналогичная ситуация зафиксирована среди представителей малого и среднего бизнеса и представителей политических партий и движений. Данные субъекты социальной структуры российского общества сегодня еще в значительной степени заявляют о неверии в положительные перспективы процесса цифровизации. 


\section{5. ФАКТОРЫ, ОТРИЦАТЕЛЬНО ВЛИЯЮЩИЕ НА ПРОЦЕСС ФОРМИРОВАНИЯ ЦИФРОВОЙ СРЕДЫ}

По степени отрицательного воздействия на процесс становления в России цифровой экономики (см. табл. 3) первое место в экспертных оценках отведено отсутствию необходимого уровня финансирования фундаментальных и прикладных исследований $(75,8$ \%), второе место заняла коррупция (69,2\%). Отметим, что получена высокая степень консолидации оценок в обеих группах экспертов.

Значительное отрицательное воздействие на процесс становления цифровой экономики оказывают, по мнению экспертов, такие социальные проблемы, как: снижение жизненного уровня населения $(64,6 \%)$, высокая степень социального расслоения общества (62,3\%), падение в обществе уровня социального оптимизма (54,3\%).

Более половины экспертов отмечают отрицательное воздействие таких социальных факторов, как отсутствие консолидации власти и общества, конфликт интересов относительно будущего России внутри властных экономических элит. Значительная часть экспертов (40,6\%) указала на негативное влияние сложившейся в стране системы стимулирования высокотехнологичного производства.

В какой мере, на Ваш взгляд, отрицательно влияют на процесс формирования в России цифровой экономики следующие факторы? ( $\mathrm{N}=127, \%$ от числа опрошенных экспертов, ранжированы по параметру «в высокой мере»)

\begin{tabular}{|c|c|c|c|c|}
\hline Ранг & Факторы влияния & $\begin{array}{c}\text { В невысокой } \\
\text { мере }\end{array}$ & $\begin{array}{c}\text { В средней } \\
\text { мере }\end{array}$ & $\begin{array}{c}\text { В высокой } \\
\text { мере }\end{array}$ \\
\hline 1 & $\begin{array}{l}\text { Отсутствие необходимого уровня } \\
\text { финансирования фундаменталь- } \\
\text { ных и прикладных исследований }\end{array}$ & 8,8 & 15,3 & 75,9 \\
\hline
\end{tabular}


Окончание табл. 3

\begin{tabular}{|c|c|c|c|c|}
\hline Ранг & Факторы влияния & $\begin{array}{c}\text { В невысокой } \\
\text { мере }\end{array}$ & $\begin{array}{l}\text { В средней } \\
\text { мере }\end{array}$ & $\begin{array}{l}\text { В высокой } \\
\text { мере }\end{array}$ \\
\hline 2 & Коррупция & 13,1 & 19,0 & 67,9 \\
\hline 3 & $\begin{array}{l}\text { Снижение жизненного уровня } \\
\text { населения }\end{array}$ & 16,5 & 18,9 & 64,6 \\
\hline 4 & $\begin{array}{l}\text { Высокая степень социального } \\
\text { расслоения общества }\end{array}$ & 19,7 & 18,1 & 62,2 \\
\hline 5 & $\begin{array}{l}\text { Отсутствие консолидации } \\
\text { общества и власти }\end{array}$ & 16,6 & 24,6 & 58,8 \\
\hline 6 & $\begin{array}{l}\text { Наличие конфликта интересов } \\
\text { относительно цифрового } \\
\text { будущего России внутри } \\
\text { властных и экономических элит }\end{array}$ & 18,4 & 23,2 & 58,4 \\
\hline 7 & $\begin{array}{l}\text { Падение в обществе уровня } \\
\text { социального оптимизма }\end{array}$ & 26,7 & 18,9 & 54,4 \\
\hline 8 & $\begin{array}{l}\text { Сложившаяся система } \\
\text { стимулирования развития } \\
\text { высокотехнологичного } \\
\text { производства в стране }\end{array}$ & 30,1 & 29,4 & 40,5 \\
\hline 9 & $\begin{array}{l}\text { Внешние вызовы в виде санкций } \\
\text { США и в целом со стороны } \\
\text { коллективного Запада }\end{array}$ & 39,3 & 20,5 & 40,2 \\
\hline 10 & $\begin{array}{l}\text { Реализуемая в стране стратегия } \\
\text { социально-экономического } \\
\text { развития }\end{array}$ & 38,0 & 32,5 & 29,5 \\
\hline 11 & $\begin{array}{l}\text { Вовлеченность страны в военные } \\
\text { действия в Сирии }\end{array}$ & 50,4 & 26,8 & 22,8 \\
\hline
\end{tabular}

Принципиально значимой выступает разница в оценках внешних и внутренних факторов отрицательного воздействия на процесс становления в России цифровой экономики. Наиболее серьезные вызовы процессу цифровизации обусловлены преимущественно внутренними причинами, внутренним состоянием российского общества. 


\section{6. СОЦИАЛЬНО-ПОЛИТИЧЕСКИЕ РИСКИ ЦИФРОВОЙ ЭКОНОМИКИ В ЭКСПЕРТНЫХ ОЦЕНКАХ}

Из анализа таблицы 4 следует, что подавляющая часть рисков соотносится экспертами с вызовами извне. К их числу относятся риск попадания персональных данных российских граждан в чужие руки, использование их в ущерб интересам России (52,9\%), захват отдельных сфер российской экономики иностранными цифровыми структурами $(45,9 \%)$ и т.д.

Иерархия социально-политических рисков цифровой экономики

Таблица 4

( $\mathrm{N}=127, \%$ от числа опрошенных экспертов, ранжированы по параметру «высокая степень вероятности проявления»)

\begin{tabular}{|c|l|c|c|c|}
\hline Ранг & \multicolumn{1}{|c|}{ Риски цифровизации } & $\begin{array}{c}\text { Наименьшая } \\
\text { вероятность }\end{array}$ & $\begin{array}{c}\text { Средняя } \\
\text { вероятность }\end{array}$ & $\begin{array}{c}\text { Наивысшая } \\
\text { вероятность }\end{array}$ \\
\hline 1 & $\begin{array}{l}\text { Рост мошенничества, } \\
\text { киберпреступности }\end{array}$ & 9,6 & 16,8 & 73,6 \\
\hline 2 & $\begin{array}{l}\text { Утечка в чужие руки } \\
\text { персональных данных } \\
\text { российских граждан, } \\
\text { использование их в ущерб } \\
\text { интересам России }\end{array}$ & 20,3 & 26,8 & 52,9 \\
\hline 3 & $\begin{array}{l}\text { Захват отдельных сфер } \\
\text { российской экономики } \\
\text { иностранными цифровыми } \\
\text { структурами }\end{array}$ & 28,3 & 25,8 & 45,9 \\
\hline 4 & $\begin{array}{l}\text { Попадание России в сферу } \\
\text { цифрового управления } \\
\text { наднациональных } \\
\text { цифровых структур }\end{array}$ & 25,5 & 32,8 & 41,7 \\
\hline 5 & $\begin{array}{l}\text { «Роботизация» людей, } \\
\text { манипуляция их сознанием }\end{array}$ & 32,3 & 26,6 & 41,1 \\
\hline
\end{tabular}


Окончание табл. 4

\begin{tabular}{|c|l|c|c|c|}
\hline Ранг & \multicolumn{1}{|c|}{ Риски цифровизации } & $\begin{array}{c}\text { Наименьшая } \\
\text { вероятность }\end{array}$ & $\begin{array}{c}\text { Средняя } \\
\text { вероятность }\end{array}$ & $\begin{array}{c}\text { Наивысшая } \\
\text { вероятность }\end{array}$ \\
\hline 6 & $\begin{array}{l}\text { Формирование «ненужных» } \\
\text { слоев населения } \\
\text { (безработицы) }\end{array}$ & 34,1 & 30,1 & 35,8 \\
\hline 7 & $\begin{array}{l}\text { Создание условий для } \\
\text { управления социально- } \\
\text { экономическими } \\
\text { процессами в России извне }\end{array}$ & 41,0 & 26,2 & 32,8 \\
\hline 8 & $\begin{array}{l}\text { Потеря суверенитета } \\
\text { в цифровой сфере }\end{array}$ & 42,0 & 24,2 & 33,8 \\
\hline 9 & $\begin{array}{l}\text { Улубление социального } \\
\text { неравенства }\end{array}$ & 38,4 & 30,4 & 31,2 \\
\hline
\end{tabular}

Около трех четвертей $(73,6 \%)$ экспертов считают риск мошенничества, киберпреступности одним из самых опасных рисков, несущих угрозу обществу, конкретному социальному субъекту.

Характерно, что экспертами не оцениваются в качестве опасных риски формирования «ненужных слоев населения (безработицы)», роботизация сферы производства.

По оценкам 70\% экспертов переход к цифровой экономике, к новому технологическому укладу поддерживается населением лишь частично. Только пятая часть (19,7\%) заявила о полной поддержке.

Существенной стороной восприятия в обществе программы перехода к цифровой экономике выступает уровень уверенности населения в реальности выполнения намеченных мер (см. табл. 5).

Таблица 5

«Как Вы считаете, сформировалась ли в обществе уверенность в реальности выполнения стратегии вхождения России в русло нового технологического уклада, цифровой экономики?»

( $\mathrm{N}=127, \%$ от числа опрошенных экспертов)

\begin{tabular}{|l|c|}
\hline Варианты ответа & $\begin{array}{c}\text { \% от общего числа } \\
\text { опрошенных }\end{array}$ \\
\hline Да, такая уверенность в обществе есть & 4,7 \\
\hline Такая уверенность сформировалась лишь частично & 54,3 \\
\hline Такой уверенности не сформировалось & 40,2 \\
\hline Затрудняюсь ответить & 0,8 \\
\hline
\end{tabular}


Все эти данные свидетельствуют о серьезном социально-политическом дисбалансе. Разработаны масштабные национальные проекты, призванные обеспечить переход России в цифровое будущее, предусмотрены серьезные финансовые ресурсы, а в обществе уверенности в их реализации нет. Меры, обозначенные в проекте цифровизации, поддерживаются лишь частично. Обращает внимание, что эксперты из числа региональных и муниципальных структур управления дали более оптимистичные оценки. Их оценка в среднем на $10 \%$ выше степени поддержки обществом принятых программ. 


\section{7. ДЕМОГРАФИЧЕСКАЯ ДИНАМИКА В РОССИИ: РИСКИ ДЛЯ НАЦИОНАЛЬНОГО ПРОЕКТА «ЦИФРОВАЯ ЭКОНОМИКА»}

Исследования свидетельствуют, что процессы цифровизации в России в предстоящие десятилетия будут сопровождаться углублением депопуляции, сокращающего возможности технологического прорыва. Прогнозные данные демографической динамики (средний вариант прогноза) до 2036 г. показывают, что численность детского населения, то есть населения, которое органичным естественным образом осваивает многие цифровые технологии, сократится, примерно, на 4,5 млн. человек и составит в 2036 г. лишь 15,8\% от численности всего населения. Значительно сократиться (на 2,8 млн человек) и численность населения в трудоспособном возрасте. Удельный вес этой группы населения снизится к 2036 г. до 54,2\% от всего населения. Напротив, в структуре населения будет увеличена доля тех, для которых освоение цифровых технологий и их использование потребует дополнительных инвестиций - это лица в пенсионном возрасте. К 2036 г. их численность увеличится на 5,7 млн человек и составит $30 \%$ всего населения.

Дефицит квалифицированных кадров обусловлен, прежде всего, сокращением роли высшего образования в структуре человеческого потенциала.

В настоящее время среди населения в возрасте 25-64 лет, имеющего высшее образование, лишь каждый третий занят в российской экономике. Численность студентов, обучающихся по образовательным программам высшего образования в расчете на 10000 человек населения, сократилась в 2017 г. относительно 2010 г. в 1,7 раза. Удельный 
вес студентов, получающих высшее образование, в общей численности населения также сократился с 4,9\% в 2010 г. до 2,9\% в 2017 г. Постоянно снижается в общей численности населения и доля студентов, обучающихся по программам подготовки квалифицированных рабочих и служащих. Если в 2010 г. она составляла 0,7\%, то в 2017 г. уже - 0,4\%. Обучающиеся на специалистов среднего звена в общей численности населения составляют, примерно, 1,5-1,6\%.

Происходит реальное сужение потребности в специалистах высшей категории, обусловленное недостаточно высоким в некоторых отраслях экономики уровнем технологического развития и организации труда, сокращением рабочих мест, требующих средней и высокой квалификации труда. Несмотря на усилия по подготовке квалифицированных специалистов IT-технологий, дефицит таких профессионалов в России продолжает оставаться выше, чем в других странах.

В связи с относительно низкой заработной платой специалистов IT-технологий в России, наблюдается их существенный отток из страны. При этом эта убыль не компенсируется миграционным притоком. Производительные расходы всей бюджетной системы, увеличивающие человеческий капитал, в проектировках Минфина РФ до 2022 года также существенно не растут. Доля расходов бюджетной системы на образование сократится с 3,8 \% в 2020 году до 3,6\% в 2022-м, а расходы на здравоохранение по отношению к ВВП составят 3,6\% в 2020 году и 3,4 \% в 2022 году.

Таким образом, демографические и образовательные процессы и их недостаточное финансирование, а также слабое научное сопровождение Национального проекта «Цифровая экономика» в современной России повышают вероятность отставания страны в технологическом соревновании и формируют риски негативных процессов в развитии человеческого потенциала. 


\section{8. ОСОБЕННОСТИ ФОРМИРОВАНИЯ НОВОЙ ЦИФРОВОЙ ЭЛИТЫ в РоССИИ}

В структуре новой элиты российского общества все более весомое место занимают социальные группы, которые уже стали или станут в ближайшее время субъектами «цифрового прорыва». Они все более активно укрепляют свои позиции в структурах власти и в политической сфере, прежде всего, как эксперты и менеджеры, способные результативно использовать достижения цифровых технологий в системе управления.

Проблема стратегической важности: какими будут политические взгляды и идеология этой новой цифровой элиты? Одним из факторов, влияющим на сущностные характеристики современной элиты, является система ее формирования. С начала 1990-х гг. в современной элите произошли следующие важные изменения:

- омоложение (средний возраст представителей современной элиты 45-50 лет);

- увеличение количества лиц, имеющих высшее образование, специалистов в области цифровых технологий, интеллектуалов и профессионалов;

- возрастание удельного веса рыночно ориентированных хозяйственников и прагматиков.

Возрастает необходимость в формировании новой более многочисленной элиты, для которой обучение и участие в новаторской и креативной деятельности станет основным приоритетом. Для этого необходимо формирование системы цифрового образования, в том числе создание электронных и интерактивных курсов для всех социальных групп населения России. Успехи российских компаний в анимации, ху- 
дожественном творчестве и программировании могут сделать их мировыми лидерами по созданию образовательного, электронного контента, если внутренний спрос будет поддержан государством.

Вместе с тем, очень важно не упустить проблему адекватного восприятия молодежью политического процесса, государственных институтов, идеологии и политических персон. Исследование подтвердило наше предположение о том, что виртуализация социальных отношений и информационной среды искажает представление, в первую очередь молодежи, о реальном мире, формирует неустойчивую картину мира, в том числе политическую. 


\section{9. РОЛЬ ГОСУДАРСТВА В ЦИФРОВОЙ ТРАНСФОРМАЦИИ РОССИЙСКОЙ ЭКОНОМИКИ}

Опыт многих наиболее развитых зарубежных стран свидетельствует, что, прежде всего, государство является основной инновационной силой в развитии цифровых технологий.

Главными направлениями активности государства в цифровой трансформации общества являются следующие:

- разработка и имплементация регулирующей законодательной базы цифрового общества и государства;

- совершенствование системы государственного управления на основе комплекса первоочередных мер, таких как переход в менеджменте от экспертных оценок к оценкам на основе данных;

- повышение квалификации государственных служащих (развитие компетенций, позволяющих анализировать большие данные и управлять изменениями);

— автоматизация основной части производственных процессов с целью исключения человеческого фактора при реализации рутинных функций;

- создание инфраструктуры содействия цифровой трансформации (экспертные советы по цифровизации на разных уровнях управления) и др.;

- обеспечение благоприятных условий для бизнеса, стимулирующих переход компаний на новые цифровые технологии;

- создание цифровой среды доверия, стимулирование спроса населения на цифровые продукты и услуги и решение проблем безопасности цифровой среды. 
Создаваемые цифровые интерфейсы взаимодействия граждан и различных государственных органов должны быть максимально доступны и дружелюбны для пользователей.

Предлагаем предусмотреть систему комплексной поддержки науки, в том числе молодых ученых по разработке научного направления «социально-политические проблемы цифровизации». 


\section{0. ОСНОВНЫЕ ВЫВОДЫ ПО І ЭТАПУ ЭКСПЕРТНОГО МОНИТОРИНГА}

Результаты исследования свидетельствуют:

- эксперты заявляют о существовании в российском обществе устойчивых социальных ожиданий, связанных с новыми возможностями цифровизации в ключевых областях социально-экономического развития России. Прежде всего, это относится к появлению прорывных технологий и росту производительности труда в промышленности и сельском хозяйстве, переходу на качественно новый уровень системы образования и медицинского обслуживания, совершенствованию государственного и муниципального управления;

- экспертное сообщество высказывает консолидированное мнение об ожидаемом позитивном влиянии процессов цифровизации на рост уровня и качества жизни населения России;

— подавляющее большинство экспертов убеждены в том, что стратегический прорыв России в число мировых лидеров возможен при условии активного освоения и внедрения цифровых технологий во всех сферах социально-экономического развития страны.

Вместе с тем отчетливо проявляется ряд негативных и опасных тенденций:

- развитие новой социально-политической реальности в условиях цифровизации носит неустойчивый, противоречивый характер и часто подвержено влиянию ситуационных факторов;

- политическая элита пока еще не в полной мере оценивает возможные последствия рисков отставания в конкурентной борьбе не только от развитых, но и быстро прогрессирующих экономик; 
— цифровой прорыв оказался вне эпицентра интересов ряда ключевых социальных групп новой российской реальности;

- процесс цифровизации, в настоящее время, не оказывает существенного позитивного влияния на социальную консолидацию российского общества, с одной стороны, и преодоление негативных процессов социальной атомизации российского общества - с другой;

- цифровизация общественной жизни в ее сегодняшних формах реализации и с учетом низкого уровня цифровой грамотности населения, слабой развитости цифровой инфраструктуры в регионах, недостаточно способствует росту доверия населения к органам власти и управления и реальному развитию институтов общественного самоуправления как основных слагаемых гражданского общества.

- информационно-коммуникационные возможности современного цифрового мира, в силу существующих политических амбиций и эгоцентричной позиции политической элиты ряда государств, пока не стали эффективным инструментом международной кооперации в научных исследованиях, многократно усиливающих интеллектуальный потенциал человечества, позволяющий успешно противостоять вызовам и рискам планетарного масштаба. 


\section{1. ПРЕДЛОЖЕНИЯ}

Методика построения иерархии социально-политических рисков позволяет операционализировать слабо формализованную экспертную информацию, что дает качественно новые возможности ее использования при построении «риск-моделей» развития социально-политического процесса в России.

Предлагаем реализацию системного, комплексного исследовательского проекта в режиме мониторинга (экспертный опрос в динамике 2 раза в год) с последующим построением «риск-моделей» социально-политического развития России, направленного на успешный переход России к новому технологическому укладу, цифровой экономике.

Полагали бы целесообразным организацию широкого обсуждения в медиа-пространстве новых возможностей цифровизации для государства, бизнеса и гражданского общества.

Согласно п. 1.4 Паспорта Федерального проекта «Цифровое государственное управление» предлагаем разработку исследовательской программы и проведение массового социологического исследования «Уровень информирования и использования населением цифровых услуг и сервисов, предоставляемых единым порталом государственных и муниципальных услуг».

Цифровое образование для разных социально-демографических групп населения должно стать основным драйвером в создании нового креативного слоя - основы цифровизации в России, и его возможности должны быть в равной степени доступны не только молодежи, но и людям старших возрастов. 
Создаваемые цифровые интерфейсы взаимодействия граждан и различных государственных органов должны быть максимально доступны и дружелюбны для пользователей.

Предлагаем предусмотреть систему комплексной поддержки науки, в том числе молодых ученых, по разработке научного направления «социально-политические проблемы цифровизации». 


\section{ЗАКЛЮЧЕНИЕ}

Стало аксиомой: мир после пандемии будет другим. Другой будет и наша страна. Какой будет новая реальность? Что не прошло проверку коронавирусом? Важнейшая задача науки объективно и достоверно ответить на эти вопросы. Определить возможные варианты и тренды формирования и развития новой реальности, риски национальной безопасности.

Для реализации такой масштабной задачи необходимы нетривиальные научные подходы, разработка актуальной теоретической парадигмы новой российской реальности. Особая роль сегодня принадлежит совершенствованию методологии и методов прогнозирования будущей российской реальности. Соблазнительно, но чрезвычайно опасно ограничиться анализом и разработкой одномерных зависимостей и тенденций.

Многие важнейшие аспекты этой проблематики непосредственно и опосредовано связаны с цифровизацией жизнедеятельности российского общества, цифровым прорывом. Процесс долгосрочного, среднесрочного и ситуационного прогнозирования развития цифровизации, как важнейший исследовательский элемент, включает подробный анализ пройденного этапа цифровой реальности, что и сделано в предлагаемой читателю брошюре.

Пандемия убедительно подтвердила многие принципиальные выводы нашего исследования. Прежде всего, вывод об определяющей роли государства и, особенно, Президента РФ, на данном этапе развития российской реальности в борьбе с пандемией. В то же время, пандемия показала низкую эффективность ряда структур государственного управления, министерств и ведомств, вынуждавших Прези28 
дента РФ включать «режим ручного управления» в ходе преодоления наиболее опасных и разрушительных социальных и экономических последствий пандемии.

Отчетливо проявились значительные различия в уровне компетентности руководства регионов, что вносит в повестку дня проблематику федеративного устройства страны.

Показали свою несостоятельность институты гражданского общества, хотя социальные сети функционировали очень активно, регулярно распространяя слухи и домыслы. Пандемия доказала огромную информационную роль сети «Интернет», которую властные структуры не смогли использовать в позитивных целях.

Оказались практически выключены из политического процесса преодоления кризиса политические партии, как парламентские, так и оппозиционные.

Карантин подверг серьезным испытаниям демографический потенциал, семейные отношения. Ожидается ухудшение демографических параметров, рост смертности, падение рождаемости, рост количества разводов и насилия в семье.

Исследования позволяют сделать вывод о том, что важнейшим трендом развития новой российской реальности останется социальный фактор, необходимость повышения качества жизни населения и снижения уровня социальной дифференциации.

Можно уверенно предположить, что процесс формирования и развития новой реальности будет сопровождаться ростом политических, экономических, демографических, социальных, техногенных, экологических и других рисков. Это повышает научную и прикладную востребованность нашего исследовательского Проекта и ответственность его участников за его результаты. Дальнейшее развитие должна получить политическая рискология. 


\section{СПИСОК ЛИТЕРАТУРЫ}

1. Бек У. Общество риска. На пути к другому модерну / Пер. с нем. В. Седельника и Н. Федоровой. М.: Прогресс-Традиция, 2000. 384 с.

2. Бочарников И. В. Информационно-коммуникативные противоречия и проблемы современных процессов глобализации // Экология внешней и внутренней среды социальной системы (ЭкоМир-9): матер. конф. (Мытищи-Москва, 29-30 марта 2018 г.). М.: Издательство МГТУ им. Н. Э. Баумана, 2019. С. 190-192.

3. Информационное пространство цифровой экономики России: концептуальные основы и проблемы формирования / А. А. Зацаринный, Э. В. Киселев [и др.]; Федеральный исследовательский центр «Информатика и управление» Российской академии наук. М.: ФИЦ ИУ РАН; ООО «НИПКЦ Восход-А», 2018. 235 с.

4. О проекте [Электронный ресурс]: Современная цифровая образовательная среда в РФ: [сайт]. URL: http://neorusedu.ru/about (дата обращения: 01.02.2020).

5. Об утверждении программы «Цифровая экономика Российской Федерации» [Электронный ресурс]: Правительство России: [сайт]. 31.07.2017. URL: http:// government.ru/docs/28653/ (дата обращения: 04.02.2020).

6. Пленарное заседание Петербургского международного экономического форума. 2 июня 2017 года [Электронный ресурс]: Президент России: [сайт]. 02.06.2017. URL: http://www.kremlin.ru/events/president/news (дата обращения: 11.03.2020).

7. Послание Президента Федеральному Собранию [Электронный ресурс]: Президент России: [сайт]. 01.12.2016. URL: http://www.kremlin.ru/events/president/ news/53379 (дата обращения: 20.01.2020).

8. Путин: формирование цифровой экономики - вопрос нацбезопасности РФ [Электронный ресурс]: TACC: [сайт]. 05.07.2017. URL: https://tass.ru/ ekonomika/4389411 (дата обращения: 18.02.2020).

9. Цифровизация [Электронный ресурс]: Викисловарь: [сайт]. 2020. URL: https:// ru.wiktionary.org/wiki/цифровизация (дата обращения: 05.03.2020).

10. Шваб K. Четвертая промышленная революция [Электронный pecypc] // mybook. ru: [сайт]. URL: https://mybook.ru/author/klaus-shvab/chetvertaya-promyshlennayarevolyuciya/read/ (дата обращения: 11.03.2020). 


\section{СВЕДЕНИЯ ОБ АВТОРАХ}

Бесхмельницин Михаил Иванович, доктор политических наук, руководитель Центра социальной безопасности и рискологии ИСПИ ФНИСЦ РАН (Руководитель коллектива).

Рогачев Сергей Владимирович, доктор экономических наук, профессор, главный научный сотрудник, руководитель Отдела методологии исследования рисков Центра социальной безопасности и рискологии ИСПИ ФНИСЦ РАН (Руководитель коллектива).

Заточная Анастасия Дмитриевна, директор ООО «Консалтинг групп».

Иванов Артур Валентинович, кандидат социологических наук, ведущий научный сотрудник ИСПИ ФНИСЦ РАН.

Кононкова Наталья Петровна, доктор экономических наук, профессор, зав. кафедрой экономики для естественных и гуманитарных факультетов Экономического факультета МГУ имени М.В. Ломоносова.

Мерзликин Николай Васильевич, кандидат философских наук, ведущий научный сотрудник ИСПИ ФНИСЦ РАН.

Сащенко Наталья Петровна, кандидат психологических наук, доцент, старший научный сотрудник ИСПИ ФНИСЦ РАН.

Сигарева Евгения Петровна, кандидат экономических наук, ведущий научный сотрудник, руководитель Отдела воспроизводства населения и демографической политики Центра социальной демографии ИСПИ ФНИСЦ РАН. 
Бесхмельницин Михаил Иванович, Рогачев Сергей Владимирович, Заточная Анастасия Дмитриевна, Иванов Артур Валентинович, Кононкова Наталья Петровна, Мерзликин Николай Васильевич, Сащенко Наталья Петровна, Сигарева Евгения Петровна

\section{ЦИФРОВИЗАЦИЯ: ЗАВТРА НАЧАЛОСЬ ВЧЕРА}

Корректор Н. С. Майорова Оформление обложки И.А. Петрович Компьютерная верстка $A . A$. Фейн

Подписано в печать 29.05.2020. Бум. офсетная. Формат 60х90 1/16. Печать офсетная. Усл. печ. л. 2. Тираж 100 экз. Заказ 335.

Издательство «Проспект» Тел.: +7 495 956-90-82

121471, Москва, ул. Рябиновая, д. 51А, стр. 1

E-mail: ofset@tcdprint.ru

Отпечатано в ООО «Издательство «Проспект» Тел.: +7 495 956-90-82

121471, Москва, ул. Рябиновая, д. 51А, стр. 1

E-mail: ofset@tcdprint.ru 